\title{
PERUBAHAN TINGKAT INFLASI DAN PENDAPATAN TIDAK KENA PAJAK TERHADAP PENERIMAAN NEGARA
}

\author{
Rahmawati \\ UIN Syarif Hidayatullah Jakarta \\ rahmawati@uinjkt.ac.id
}

\begin{abstract}
.
These research purposes for knowing the influence change of inflation rate and nontax revenue (PTKP) to the state income from tax revenue (PPh 21). Data that has used in this research are primary and secondary which has taken from DJP, BPS and other relevant sources. This data used classic assumption test and multiple linear regressions. Research result showed that the changing of inflation rate and changing of nontax revenue (PTKP) had a significant effect to state income. Although mathematically the increasing of nontax revenue (PTKP) should decrease state income from tax, according to this research, the increasing of nontax revenue (PTKP) otherwise also increasing state income from tax. These mean that the government policy for increasing nontax revenue (PTKP) already correct policy.
\end{abstract}

Keywords: Inflation Rate, NonTax Revenue (PTKP), State Income From Tax Revenue (PPh 21)

\begin{abstract}
Abstrak.
Tujuan penelitian ini untuk mengetahui pengaruh perubahan tingkat inflasi dan pendapatan non-pajak (PTKP) terhadap pendapatan negara dari penerimaan pajak (PPh 21). Data yang telah digunakan dalam penelitian ini adalah primer dan sekunder yang diperoleh dari DJP, BPS dan sumber-sumber lain yang relevan. Data ini menggunakan uji asumsi klasik dan regresi linier berganda. Hasil penelitian menunjukkan bahwa perubahan tingkat inflasi dan perubahan pendapatan non-pajak (PTKP) memiliki pengaruh yang signifikan terhadap pendapatan negara. Meskipun secara matematis meningkatnya pendapatan non-pajak (PTKP) harus menurunkan penerimaan negara dari pajak, menurut penelitian ini, peningkatan pendapatan nonpajak dari (PTKP) dinyatakan juga akan meningkatkan pendapatan negara dari pajak. Ini berarti bahwa kebijakan pemerintah untuk meningkatkan pendapatan non-pajak (PTKP) merupakan kebijakan yang tepat.
\end{abstract}

Kata Kunci: Nilai Tukar, Inflasi, DDI, FDI, Krisis 


\section{PENDAHULUAN}

Indonesia mengalami keterpurukan sejak dilanda kegoncangan politik pada tahun 1996/1997. Kekisruhan yang terjadi di dunia politik berdampak pada perekonomian bangsa Indonesia pada saat itu. Bank Indonesia tidak dapat mempertahankan kestabilan nilai rupiah hingga jatuh ke nilai paling rendah. Nilai tukar rupiah terhadap Dollar Amerika menurun drastis, bahkan sempat menyentuh angka Rp. 20.000 untuk 1 Dollar Amerika. Banyak perusahaan mengalami kebangkrutan karena tidak mampu memenuhi biaya produksi, akibatnya tingkat pengangguran meningkat tajam. Pada saat itu inflasi mencapai 70 persen, dan pendapatan nasional menurun sebesar 13 persen.

Seiring membaiknya kondisi politik bangsa Indonesia, perekonomian yang sempat terjerembab perlahan-lahan mulai bangkit, nilai tukar rupiah terhadap Dollar Amerika mulai stabil di kisaran Rp. 10.000. Inflasi yang menurun drastis hingga di bawah 15 persen membuat dunia usaha kembali bangkit dan sedikit demi sedikit tingkat pengangguran dapat dikurangi. Pemerintah dengan kebijakan moneter dan fiskal berusaha untuk dapat mempertahankan kondisi yang telah berangsur normal. Berbagai peraturan dan perundangan dibuat pemerintah untuk menciptakan lingkungan yang semakin kondusif dalam dunia usaha.

Salah satu perubahan yang dilakukan oleh pemerintah adalah melakukan reformasi di bidang perpajakan pada tahun 2000 yang sebelumnya dilakukan pada tahun 1994. Perubahan tersebut meliputi Ketentuan Umum dan Tata Cara Perpajakan Pajak Penghasilan, Pajak Pertambahan Nilai, Pajak Penjualan Atas Barang Mewah, Bea Peralihan Hak Atas Tanah dan Bangunan, serta Pajak Daerah dan Retribusinya. Perubahan ini membawa dampak yang positif bagi Wajib Pajak, karena reformasi pajak tahun 2000 telah memperhitungkan kepentingan dunia bisnis antara lain dengan peningkatan pelayanan, penyederhanaan prosedur, kepastian hukum, keadilan, dan pemberian fasilitas investasi untuk mendorong kegiatan investasi (Suandi, 2002). Tujuan dari reformasi perpajakan yang dilakukan oleh pemerintah adalah intensifikasi dan ekstensifikasi pengenaan pajak yang dilakukan dengan cara mencari objek pajak yang potensial untuk menghimpun dana dan mendorong pemulihan perekonomian.

Selain mengeluarkan peraturan perpajakan, pemerintah berusaha menjaga kestabilan tingkat inflasi, selama tahun 2001 inflasi diperkirakan mencapai 11,9 persen yang di 
sebabkan oleh melemahnya kurs rupiah yang diikuti dengan kenaikan harga bahan bakar minyak (BBM) dan tarif dasar listrik (TDL) pada bulan Juni, serta tingginya permintaan akan barang dan jasa yang disebabkan oleh berlangsungnya hari raya keagamaan secara bersamaan menjelang akhir tahun. Kebijakan pemerintah untuk menaikkan harga BBM dan TDL tersebut telah mendorong inflasi yang cukup tinggi dalam bulan Juli yang mencapai 2,12 persen. Meskipun inflasi bulan Agustus 2001 mengalami inflasi negatif sebesar 0,21 persen, namun menjelang akhir tahun, laju inflasi mengalami peningkatan yang cukup tajam hingga mencapai 17,2 persen dalam bulan November 2001 yang disebabkan oleh meningkatnya permintaan menjelang berlangsungnya hari raya keagaaman.

Penerimaan PPh dalam tahun anggaran 2001 meningkat cukup signifikan, yakni dari Rp 72,7 triliun (6,4 persen terhadap PDB) dalam tahun anggaran 1999/2000, menjadi Rp 92,8 triliun (6,3 persen terhadap PDB), yang berarti meningkat Rp20,1 triliun. Selain karena pengaruh perkembangan kondisi ekonomi makro, peningkatan penerimaan juga merupakan hasil dari upaya; (i) ekstensifikasi wajib pajak terutama melalui program penyisiran pencairan tunggakan secara aktif, (ii) peningkatan penyuluhan, pelayanan kepada wajib pajak, serta pemeriksaan sederhana di lapangan, dan (iii) perbaikan administrasi dan penegakan hukum.

Dalam tahun 2002 laju inflasi diperkirakan akan menurun menjadi 9,0 persen karena; (i) menguatnya nilai tukar rupiah sejalan dengan meningkatnya kepercayaan masyarakat terhadap perekonomian Indonesia, (ii) tersedianya barang dan jasa dalam jumlah yang cukup dan semakin lancarnya distribusi, sejalan dengan semakin dinamisnya perekonomian daerah, (iii) kebijakan fiskal yang hati-hati melalui pengendalian defisit APBN yang diupayakan turun dari sekitar 3,7 persen dari produk domestik bruto (PDB) dalam tahun 2001 menjadi sekitar 2,5 persen dalam tahun 2002, dan (iv) kebijakan moneter yang hati-hati dan konsisten dengan target pertumbuhan uang primer sebesar 12-14 persen.

Penerimaan perpajakan dalam tahun anggaran 2002 ditetapkan mencapai Rp219,6 triliun (13,0 persen terhadap PDB), sejalan dengan membaiknya berbagai variabel yang menentukan penerimaan perpajakan, seperti pertumbuhan ekonomi, perkembangan tingkat harga umum, dan nilai tukar rupiah terhadap dolar Amerika Serikat. Untuk mendukung tercapainya sasaran penerimaan, akan ditempuh berbagai kebijakan yang meliputi upaya intensifikasi 
pemungutan pajak, ekstensifikasi subjek/objek pajak, dan peningkatan pelayanan kepada wajib pajak. Kebijakan umum tersebut diimplementasikan terhadap semua jenis pajak, yang selanjutnya masing-masing akan dijabarkan secara spesifik dalam kebijakan operasionalnya.

Berdasarkan asumsi besaran variabel ekonomi makro yang diperkirakan akan dicapai dalam tahun anggaran 2002, serta didukung oleh berbagai kebijakan yang telah dan akan ditempuh di bidang pajak penghasilan (PPh), penerimaan PPh direncanakan mencapai Rp104,5 triliun (6,2 persen terhadap PDB), yang terdiri dari PPh nonmigas Rp88,8 triliun (5,3 persen terhadap PDB) dan PPh migas Rp15,7 triliun (0,9 persen terhadap PDB) yang berarti bahwa penerimaan PPh secara rasio terhadap PDB mengalami penurunan sebesar 0,1 persen terhadap PDB dibandingkan tahun anggaran 2001 yang mencapai Rp 92,8 triliun atau 6,3 persen terhadap PDB. Hal ini disebabkan oleh menurunnya penerimaan PPh migas, meskipun peran PPh nonmigas makin meningkat.

Penerimaan PPh nonmigas dalam tahun anggaran 2002 ditetapkan 27,4 persen lebih tinggi dari sasaran tahun anggaran 2001 yang dipengaruhi oleh faktor eksternal dan internal, baik yang berdampak positif maupun negatif. Faktor eksternal yang berdampak positif antara lain adalah pertumbuhan ekonomi makro yang diperkirakan lebih baik dari tahun sebelumnya, yang akan berdampak positif terhadap peningkatan basis pemungutan PPh nonmigas. Sementara itu, faktor internal berkaitan dengan berbagai kebijakan yang telah dan akan ditempuh di bidang PPh. Kebijakan yang ditempuh di bidang PPh nonmigas antara lain penerapan Undang-Undang Nomor 17 Tahun 2000 tentang Pajak Penghasilan, upaya ekstensifikasi melalui kerjasama dengan RT/RW agar setiap kartu keluarga diberi Nomor Pokok Wajib Pajak (NPWP), dan mewajibkan bagi orang pribadi yang memperoleh penghasilan di atas Penghasilan Tidak Kena Pajak (PTKP) untuk menjadi wajib pajak. Di samping itu, juga akan di berlakukan perubahan terhadap perundang-undangan yang selama ini merupakan faktor penghambat bagi pelaksanaan intensifikasi dan ekstensifikasi perpajakan. Perubahan undang-undang tersebut meliputi amandemen atas Undang-Undang tentang Perbankan (Undang-Undang Nomor 10 Tahun 1998), serta ketentuan tentang monitoring lalu lintas devisa dan pencatatan transaksi keuangan yang memberikan akses kepada aparat pajak. Kebijakan pendukung lainnya adalah pengembangan sistem informasi dan monitoring perpajakan yang terintegrasi dan on-line antar unit-unit terkait. Dalam hal pemberlakuan kebijakan mengenai pengampunan pajak (tax 
amnesty) saat ini masih diperlukan persiapan yang matang dan teliti dalam pelaksanaannya, serta perlu ditekankan bahwa kebijakan tersebut hanya dilakukan sekali saja, tidak berulang-ulang, dengan demikian, diharapkan tidak menimbulkan hasil yang kontraproduktif.

Sasaran penerimaan PPh migas dalam APBN 2002 di perkirakan menurun Rp7,4 triliun atau 32,0 persen dari kondisinya dalam tahun 2001, target penerimaan PPh migas tersebut didasarkan atas asumsi produksi minyak diperkirakan 1.320 MBCD, harga minyak US\$22 per barel, dan nilai tukar Rp9.000,00 per US\$. Laju inflasi tahun 2003 dapat dikendalikan pada tingkat yang rendah yaitu 5,06 persen, kembali meningkat hingga mencapai 6,40 persen tahun 2004. Memasuki tahun 2005, laju inflasi menunjukkan peningkatan yang cukup tajam, dan cenderung menurun sejak bulan April dari 8,81 persen (y-o-y) pada bulan Maret menjadi 7,84 persen pada bulan Juli 2005.

Perkembangan laju inflasi kumulatif selama Januari - Juli 2005 sebesar 5,09 persen jauh lebih tinggi dibandingkan inflasi kumulatif periode yang sama tahun sebelumnya sebesar 3,69 persen. Inflasi pada periode tersebut dipengaruhi oleh meningkatnya harga BBM, bencana tsunami di NAD dan Sumatera Utara, masih tingginya ekspektasi inflasi, serta meningkatnya harga barang impor terkait dengan melemahnya nilai tukar rupiah serta meningkatnya harga minyak mentah di pasaran internasional. Selain itu, kenaikan harga jual eceran (HJE) rokok sebesar 15 persen serta meningkatnya uang sekolah pada bulan Juli 2005 juga turut mendorong meningkatnya inflasi pada periode tersebut. Dalam bulan-bulan mendatang inflasi diperkirakan masih akan mengalami tekanan terkait dengan masih tingginya harga minyak dunia serta faktor musiman seperti Lebaran, Natal, dan tahun baru.

Kebijakan pemerintah menaikkan BBM telah menjadi pembicaraan luas di masyarakat, memicu pro kontra di masyarakat. Sebagian besar masyarakat merasa pemerintah semakin tidak membela rakyat kecil, kenaikan harga BBM dirasa sangat memberatkan, karena akan berakibat pada meningkatnya harga kebutuhan pokok dan menurunnya daya beli masyarakat. Pada bulan Nopember 2004, pemerintah mengeluarkan kebijakan perpajakan yang berpihak pada masyarakat kecil yang di harapkan dapat menurunkan beban pajak masyarakat. Kebijakan pajak tersebut adalah: Pertama, kenaikan Penghasilan Tidak Kena Pajak (PTKP) yang mulai di berlakukan pada tahun pajak 2005, sesuai dengan KMK (Keputusan Menteri Keuangan) Nomor 
564/KMK.03/2004. PTKP yang semula sebesar Rp 2.880.000 untuk wajib pajak orang $\begin{array}{lllll}\text { pribadi meningkat menjadi Rp12.000.000. (NN, dalam } & \end{array}$ http://www.infofiskal.com/edisiperdana+tahun2005).

Kenaikan PTKP yang cukup signifikan diharapkan beban pajak yang ditanggung masyarakat, terutama PPh tidak lagi membebani masyarakat. Dampak fiskal yang dihadapi pemerintah dalam jangka pendek adalah berkurangnya penerimaan PPh (potential loss). Namun, dalam jangka panjang diharapkan berdampak positif terhadap penerimaan perpajakan. Hal ini disebabkan karena berkurangnya beban pajak akan meningkatkan konsumsi masyarakat yang pada gilirannya akan meningkatkan pertumbuhan ekonomi (dampak makro) sehingga dasar pengenaan pajak meningkat, di sisi lain menyebabkan timbulnya potensi kehilangan (potential loss) pada penerimaan PPh nonmigas.

Kedua, penghapusan PPnBM pada beberapa produk yang diatur dalam Peraturan Pemerintah (PP) Nomor 55 Tahun 2004 tertanggal 31 Desember 2004. Dalam PP tersebut beberapa kelompok barang yang semula dibebani PPnBM sebesar 10 hingga 20 persen kini dihapuskan menjadi nol persen, antara lain kelompok kepala susu atau susu yang di asamkan, kelompok air buah dan air sayuran, serta kelompok minuman yang tidak mengandung alkohol. Hal itu juga berlaku pada produk kecantikan dan kelompok permadani tertentu selain yang terbuat dari serabut kelapa, sutra, wol, dan bulu hewan halus (Info Fiskal, 2005).

Dampak fiskal diharapkan netral terhadap penerimaan negara, karena di hapuskannya PPnBM, maka penghapusan diteruskan kepada konsumen akhir melalui penurunan harga barang yang akan mengakibatkan meningkatnya permintaan atas kelompok barang, sehingga penjualan meningkat dan penerimaan pajak lainnya (PPN, PPh Badan, dan PPh pasal 21) juga akan meningkat. Selain itu, bagi industri, penghapusan PPnBM akan membuat barang produksinya menjadi kompetitif dan mengurangi penyelundupan, sehingga mereka akan meningkatkan investasi yang akan menyerap tenaga kerja dan meningkatkan pertumbuhan ekonomi.

Dengan adanya dua kebijakan itu, pemerintah mengharapkan beban pajak yang ditanggung masyarakat akan semakin berkurang, sehingga tingkat kesejahteraan masyarakat dapat ditingkatkan. Kenaikan harga BBM memang memberatkan, tetapi dengan adanya kedua kebijakan itu kenaikan harga dapat dikompensasi. Asumsi faktor lainnya tetap, maka setiap ada perubahan inflasi sebesar 1 persen (100 basis point), 
akan berpengaruh pada pendapatan negara sekitar Rp3,1 triliun, masing-masing berasal dari PPh nonmigas Rp1,4 triliun, serta PPN, PPnBM, dan pajak-pajak lainnya Rp1,7 triliun, dan sebagai konsekuensinya, belanja negara, khususnya dana perimbangan juga akan naik sekitar Rp0,9 triliun, dengan demikian, setiap perubahan (kenaikan) inflasi dengan 1 persen secara neto akan berdampak pada penurunan defisit Rp2,2 triliun, dan kelebihan pembiayaan Rp2,2 triliun, dan sebaliknya jika terdapat penurunan inflasi.

Apabila dilihat dari besarnya Pendapatan Tidak Kena Pajak (PTKP) yang semakin tinggi dapat menurunkan penerimaan PPh nonmigas khususnya PPh pasal 21 , karena dengan semakin besarnya PTKP jumlah pajak yang dibayarkan oleh Wajib Pajak semakin kecil (Budianto, 2005). Namun, dengan usaha pemerintah yang terus menggalakkan intensifikasi dan ekstensifikasi perpajakan (khususnya PPh pasal 21), penerimaan pemerintah dari sektor pajak tidak mengalami perubahan berarti yang memerlukan penelitian secara lebih mendalam.

Salah satu tujuan pemerintah menaikkan PTKP adalah untuk meningkatkan kesejahteraan para karyawan, yang sebagian besar merupakan Wajib Pajak PPh pasal 21. Secara makro, tindakan pemerintah menaikkan PTKP adalah untuk menjaga kestabilan inflasi. Pertama, inflasi yang tinggi akan menyebabkan pendapatan riil masyarakat akan terus menurun sehingga standar hidup dari masyarakat menjadi rendah dan mempertinggi tingkat kemiskinan. Kedua, inflasi yang tidak stabil akan menciptakan ketidakpastian (uncertainty) bagi pelaku ekonomi dalam mengambil keputusan. Pengalaman empiris menunjukkan bahwa inflasi yang tidak stabil akan menyulitkan keputusan masyarakat dalam melakukan konsumsi, investasi dan produksi, pada akhirnya akan menurunkan pertumbuhan ekonomi. Ketiga, inflasi domestik yang lebih tinggi dibanding dengan inflasi di negara tetangga menjadikan tingkat bunga domestik riil menjadi tidak kompetitif sehingga dapat memberikan tekanan pada nilai rupiah.

\section{METODE}

Penelitian ini mencakup dalam bidang analisis keuangan dan perpajakan dengan mengumpulkan data mengenai tingkat inflasi, penerimaan negara dari pajak penghasilan pasal 21, dan penghasilan tidak kena pajak (PTKP). Penelitian ini merupakan penelitian kausalitas, karena tujuan penelitian ini adalah meneliti hubungan sebab akibat antara dua variabel, yaitu variabel dependen (penerimaan negara dari 
pajak penghasilan pasal 21) dan variabel independen (tingkat inflasi dan pendapatan tidak kena pajak).

Penerimaan negara bersumber dari pajak dan non pajak. Penerimaan negara di pengaruhi oleh banyak faktor seperti tingkat inflasi salah satunya. Salah satu sumber penerimaan negara dari pajak adalah pajak penghasilan pasal 21 (PPh 21). Besarnya pajak penghasilan pasal 21 (PPh 21) sangat di pengaruhi oleh Pendapatan Tidak Kena Pajak (PTKP). Oleh karena itu, penulis mencoba untuk meneliti pengaruh antara perubahan tingkat inflasi dan Pendapatan Tidak Kena Pajak (PTKP) terhadap penerimaan negara khususnya dari Pajak Penghasilan pasal 21 (PPh 21). Untuk meneliti hubungan antara perubahan tingkat inflasi dan Pendapatan Tidak Kena Pajak (PTKP) terhadap Penerimaan Negara dari PPh 21 peneliti menggunakan analisis Regresi Linier Berganda sebagai instrumen penguji. Adapun hipotesis yang dirumuskan dalam penelitian ini adalah:

HO : Perubahan tingkat inflasi dan Pendapatan Tidak Kena Pajak (PTKP) tidak berpengaruh terhadap penerimaan negara dari pajak penghasilan pasal 21 (PPh 21)

HA : Perubahan tingkat inflasi dan Pendapatan Tidak Kena Pajak (PTKP) berpengaruh terhadap penerimaan negara dari pajak penghasilan pasal 21 (PPh 21)

Model statistik yang dipakai adalah model regresi linear berganda, yaitu suatu teknik yang digunakan untuk menghitung seberapa jauh hubungan antara beberapa variabel bebas (independen) dengan variabel terikat (dependen). Model regresi linear berganda dapat dirumuskan sebagai berikut :

$$
Y=a+b_{1} X_{1}+b_{2} X_{2}+e
$$

Keterangan:

Y

a

$\mathrm{X}_{1}$

$\mathrm{X}_{2}$

e

= Variabel dependen (Penerimaan Negara dari PPh 21)

$=$ Konstanta

$=$ Variabel independen (Tingkat Inflasi)

$=$ Variabel independen (PTKP)

$=$ Standard error 


\section{Operasional Variabel Penelitian}

Dalam penelitian ini terdapat tiga variabel, yaitu :

1. Variabel Bebas (Independent Variable)

Dalam penelitian ini yang menjadi independent variabel adalah tingkat inflasi dan pendapatan tidak kena pajak.

2. Variabel Terikat (Dependent Variable)

Dalam penelitian ini yang menjadi variabel terikat adalah penerimaan negara dari pajak penghasilan pasal 21.

\section{HASIL DAN PEMBAHASAN}

Tabel 1. Hasil Uji Multikolinieritas

\begin{tabular}{ccc}
\hline \multirow{2}{*}{ Model } & \multicolumn{2}{c}{ Collinearity Statistics } \\
\cline { 2 - 3 } & & \multicolumn{2}{c}{ Tolerance } & VIF \\
\hline & & \\
Tingkat Inflasi & .975 & 1.026 \\
PTKP & .975 & 1.026 \\
\hline
\end{tabular}

Sumber : Hasil Pengolahan

Berdasarkan tabel 1, nilai tolerance adalah sebesar 0,975 dan nilai VIF adalah sebesar 1,026. Maka dapat diambil kesimpulan bahwa model regresi ini bebas multiko atau tidak ditemukan adanya korelasi antar variabel tingkat inflasi dengan PTKP. Ini menunjukkan bahwa apabila terjadi kenaikan tingkat inflasi tidak mempunyai hubungan/pengaruh terhadap besar/kecilnya PTKP. Hasil Uji Koefisien Determinasi (Adjusted R-Square)

Tabel 2. Koefisien Determinasi

\begin{tabular}{rrrrr}
\hline Model & $\mathrm{R}$ & $R$ Square & $\begin{array}{c}\text { Adjusted } R \\
\text { Square }\end{array}$ & $\begin{array}{c}\text { Std Error of the } \\
\text { estimate }\end{array}$ \\
\hline 1 & .527 & .278 & .209 & 1449628.238 \\
\hline
\end{tabular}

Sumber : Diolah Sendiri

Besarnya koefisien determinasi pada tabel diatas adalah sebesar 0.209 atau 20,9 \%. Artinya 20,9 \% bahwa variabel penerimaan negara dari PPh 21 dapat dijelaskan oleh perubahan tingkat inflasi dan perubahan Pendapatan Tidak Kena Pajak (PTKP), sedangkan sisanya dijelaskan oleh faktor-faktor lain. Uji Statistik F dilakukan untuk mengetahui hubungan variabel independen secara bersama-sama (simultan) terhadap variabel dependen. 
Tabel 3. Hasil Uji F Statistik

\begin{tabular}{lrrrrr}
\hline \multicolumn{1}{c}{ Model } & Sum of Squares & df & Mean Square & F & \multicolumn{1}{c}{ Sig. } \\
\hline Regression & $2 \mathrm{E}+013$ & 2 & $8.489 \mathrm{E}+012$ & 4.040 & $.033^{\mathrm{a}}$ \\
Residual & $4 \mathrm{E}+013$ & 21 & $2.101 \mathrm{E}+012$ & & \\
Total & $6 \mathrm{E}+013$ & 23 & & & \\
\hline
\end{tabular}

Tabel 3. menunjukkan hasil uji $F$ dengan signifikansi 0,033 dimana besarnya signifikansi dari hasil uji $\mathrm{F}$ tersebut lebih kecil dari 0,05 . Hal ini berarti penelitian ini menerima HA (Ho ditolak), artinya variabel perubahan tingkat inflasi dan Pendapatan Tidak Kena Pajak (PTKP) berpengaruh terhadap variabel Penerimaan Negara dari PPh 21.

Tabel 4. Koefisien Regresi

\begin{tabular}{|c|c|c|c|c|c|}
\hline \multirow[b]{2}{*}{ Model } & \multicolumn{2}{|c|}{$\begin{array}{c}\text { Unstandardized } \\
\text { Coefficients }\end{array}$} & $\begin{array}{l}\text { Standardized } \\
\text { Coefficients }\end{array}$ & \multirow[b]{2}{*}{$t$} & \multirow[b]{2}{*}{ Sig. } \\
\hline & B & Std. Error & Beta & & \\
\hline (Constant) & 4997408.9 & 571036.87 & & 8.751 & .000 \\
\hline Tingkat Inflasi & 65224.582 & 146635.82 & .084 & .445 & .661 \\
\hline PTKP & .059 & .022 & .507 & 2.702 & .013 \\
\hline
\end{tabular}

a. Dependent Variabel : Penerimaan Negara dari PPh 21

Dari tabel 4 diperoleh persamaan regresi sebagai berikut: $Y=4.997 .408,9+$ $65.224,582 \times 1+0,059 \times 2+$ e Nilai signifikansi antara variabel tingkat inflasi dengan penerimaan negara adalah sebesar 0.661 atau lebih besar dari 0,05 yang berarti variabel tingkat inflasi tidak mempunyai pengaruh signifikan terhadap variabel penerimaan negara dari PPh 21. Sedangkan nilai signifikansi antara variabel PTKP dengan penerimaan negara dari PPh 21 adalah sebesar 0,013 atau lebih kecil dari 0,05 yang berarti variabel PTKP mempunyai pengaruh signifikan terhadap penerimaan negara dari PPh 21.

\section{SIMPULAN}

Penelitian menolak H0. Maka, dapat disimpulkan bahwa perubahan tingkat inflasi dan Pendapatan Tidak Kena Pajak (PTKP) secara bersama-sama (simultan) berpengaruh terhadap variabel Penerimaan Negara dari PPh 21. Hasil ini diperoleh berdasarkan Uji F Statistik, besarnya signifikansi adalah 0,033, dimana hasil uji $F$ tersebut lebih kecil dari 0,05. Kebijakan pemerintah untuk menaikkan Pendapatan Tidak Kena Pajak (PTKP) sudah tepat. Walaupun secara matematis kenaikan PTKP dapat menurunkan 
penerimaan negara dari PPh 21, namun berdasarkan data dan hasil penelitian yang telah penulis lakukan, kenaikan PTKP justru menambah penerimaan negara dari PPh 21. Penerimaan Negara sangat bergantung terhadap kebijakan yang ditetapkan oleh pemerintah. Kesalahan dalam penerapan kebijakan baik di bidang moneter maupun fiskal akan berdampak pada berkurangnya penerimaan negara.

\section{PUSTAKA ACUAN}

Budianto, Triyani. 2005. Penyesuaian Besarnya PTKP dan Implikasinya Terhadap PPh Pasal 21 Tahun 2005. Jurnal Perpajakan Indonesia, Volume 4, No. 4.

BPS. Buletin Statistik Bulanan. Indikator Ekonomi. Jakarta : Badan Pusat Statistika.

Ghozali, Imam. 2005. Aplikasi Analisis Multivariate dengan Program SPSS. Edisi 3. Semarang : Badan Penerbit Universitas Diponegoro

Ika, Siti Rochmah. 2005. Analisis Efisiensi Perusahaan Manufaktur Yang Terdaftar Di Bursa Efek Jakarta Sebelum dan Sesudah Berlakunya UndangUndang Perpajakan 2000. Makalah Seminar Nasional Akuntansi VIII. Solo.

Indriantoro, Nur dan Bambang Supomo, 2002. Metodologi Penelitian Bisnis Untuk Akuntansi \& Manajemen. Edisi Pertama. Yogyakarta : BPFE.

Pratono, A. Hery dan Soedarjanto. 2001. Analisis Kausalitas Antara Pertumbuhan Ekonomi dengan Inflasi. Jurnal Ekonomi dan Bisnis, Volume 3, No. 2.

Radianto, Wirawan Endro Dwi. 2005. Analisis Efisiensi Perusahaan Bank Yang Terdaftar Di BEJ Sebelum dan Sesudah Diberlakukannya UndangUndang Perpajakan 2000. Jurnal Riset Akuntansi Dan Keuangan, Volume 4, No. 2.

Resmi, Siti. 2005. Perpajakan Teori dan Kasus. Edisi Kedua. Jakarta : Salemba Empat

Santoso, Singgih. 2001. SPSS Mengolah Data Statistik Secara Profesional. Jakarta : Elek Komputindo.

Siregar, Baldric dan Bonni Siregar. 2001. Akuntansi Pemerintahan dengan Sistem Dana. Yogyakarta: Aditya Media

Suandi, Erly. 2002. Hukum Pajak. Edisi Kedua. Jakarta : Salemba Empat

Sukirno, Sadono. 2004. Makro Ekonomi Teori Pengantar. Cetakan 16. Jakarta : PT. Raja Grafindo Persada 
Umar, Husein. 2005. Metode Penelitian Untuk Skripsi dan Tesis Bisnis. Jakarta: PT. Raja Grafindo Persada

Wibowo, Tri. 2000. Dampak Penerimaan Pajak Terhadap Pendapatan Nasional. dalam Jurnal Kipas, Volume 2, No. 24. 